\title{
Trends and advances in tumor immunology and lung cancer immunotherapy
}

\author{
Mohanad Aldarouish ${ }^{*}$ and Cailian Wang ${ }^{*}$
}

\begin{abstract}
Among several types of tumor, lung cancer is considered one of the most fatal and still the main cause of cancerrelated deaths. Although chemotherapeutic agents can improve survival and quality of life compared with symptomatic treatment, cancers usually still progress after chemotherapy and are often aggravated by serious side effects. In the last few years there has been a growing interest in immunotherapy for lung cancer based on promising preliminary results in achieving meaningful and durable treatments responses with minimal manageable toxicity. This article is divided into two parts, the first part discusses the role of human immune system in controlling and eradicating cancer and the mechanisms of immune response evasion by tumor. The second part reviews the recent progress made in immunotherapy for lung cancer with results from trials evaluating therapeutic vaccines in addition to immune checkpoint blockade, specifically cytotoxic T lymphocyte associated protein 4, programmed death receptor 1 pathway, using monoclonal antibodies.
\end{abstract}

Keywords: Lung cancer, Tumor immunology, Immunotherapy, Cancer vaccines, Clinical trials, Immune checkpoint inhibitors

\section{Background}

Lung cancer is the leading cause of cancer death and the second most common cancer in the world. According to 2012 GLOBOCAN estimation, the total number of lung cancer new cases was about 1.8 million worldwide. In China, 652842 new cases were recorded in 2012 compared with 733280 new cases in 2015 [1]. For years the standard treatment strategies of lung cancer have been surgery, chemotherapy, radiation therapy and targeted therapy [2]. Recently, tumor immunotherapy is attracting the most attention among different therapeutic options for treatment of lung cancer.

Cancer immunotherapy is a type of cancer treatment designed to boost the body's natural defenses against cancer. It is divided into two categories, passive and active immunotherapy. Passive immunotherapy is defined as an administration of agents such as monoclonal antibodies or adaptive cell therapy that directly target tumor [3, 4]. Whereas, active immunotherapy aims to stimulate the hosts own immune system to eradicate cancer depending

\footnotetext{
*Correspondence: imm_moh@yahoo.com; wangcailian65@hotmail.com Department of Oncology, Zhongda Hospital, School of Medicine, Southeast University, 87 Dingjiagiao Rd, Nanjing, Jiangsu Province, People's Republic of China
}

(c) 2016 The Author(s). Open Access This article is distributed under the terms of the Creative Commons Attribution 4.0 International License (http://creativecommons.org/licenses/by/4.0/), which permits unrestricted use, distribution, and reproduction in any medium, provided you give appropriate credit to the original author(s) and the source, provide a link to the Creative Commons license, and indicate if changes were made. The Creative Commons Public Domain Dedication waiver (http://creativecommons.org/publicdomain/zero/1.0/) applies to the data made available in this article, unless otherwise stated. on vaccination with tumor antigens, non-specific immunomodulation using bacterial products, or targeting negative regulatory receptors that prevent the development of the tumor immune response [5]. Finally, it should be noted that efficient tumor immunotherapy must induce a potent anti-tumor immune response and overcome the effect of tumor immunosuppression [6].

\section{Cancer immunology}

Both innate immunity (Fig. 1) and adaptive immunity (Fig. 2) play a crucial role in antitumor immune response. Innate immunity is composed of macrophages, granulocytes, mast cells, DCs and natural killer (NK) cells. Whereas, adaptive immunity is composed of B cells, $\mathrm{CD}^{+}$cytotoxic lymphocytes (CTLs) and $\mathrm{CD} 4^{+}$ helper T cells. It must be mentioned that NK cells and ${ }_{\gamma} \delta \mathrm{T}$ cells play at the interface between innate and adaptive immunity $[7,8]$. The roles of innate and adaptive immunity in controlling and eradicating cancers are discussed below.

CTLs are considered the backbone of immune response against tumor. Several studies have reported that tumor-infiltrating lymphocytes TILs (mononuclear cells derived from the inflammatory infiltrate in human solid 

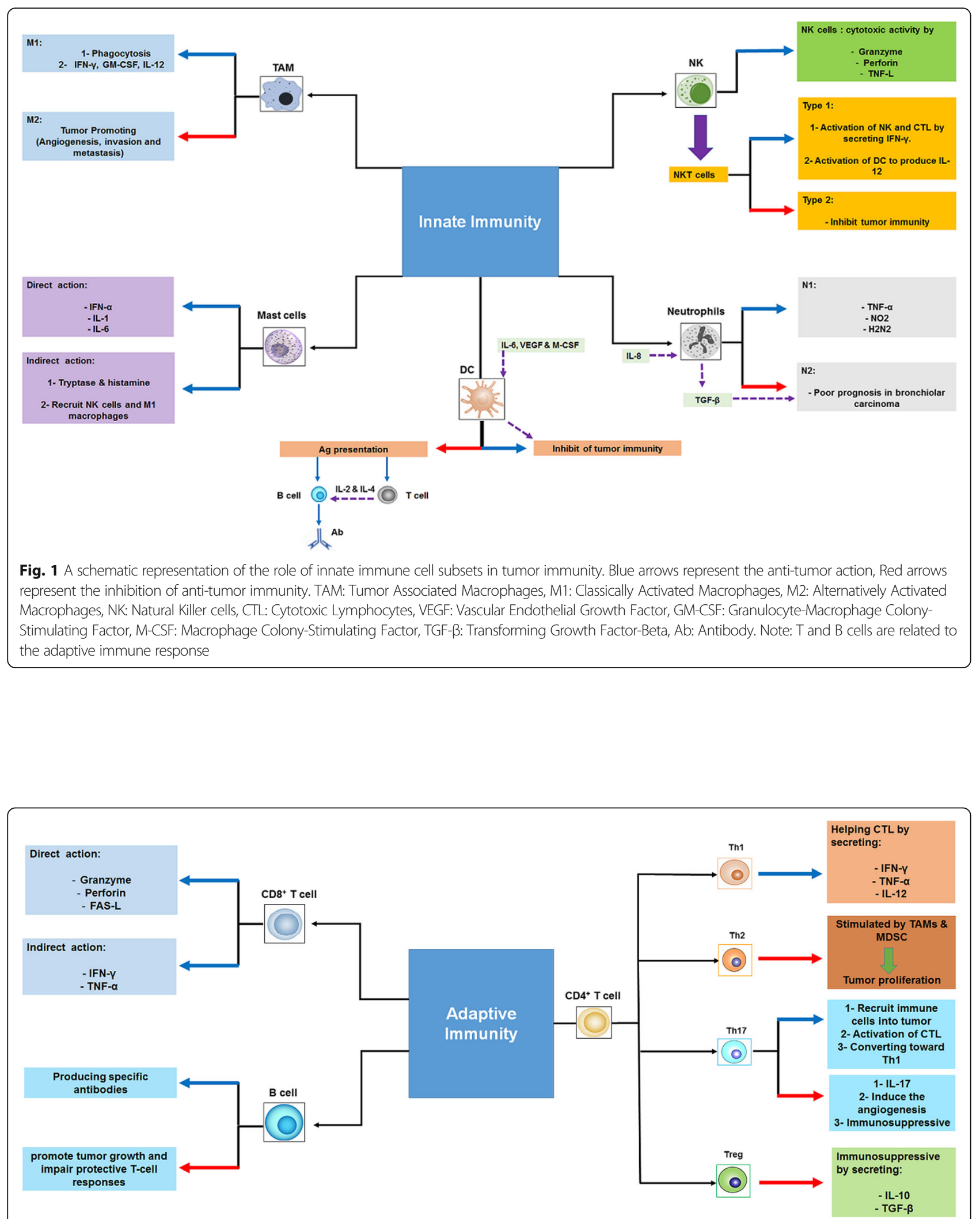

Fig. 2 A schematic representation of the role of adaptive immune cell subsets in tumor immunity. Blue arrows represent the anti-tumor action, Red arrows represent the inhibition of anti-tumor immunity. TNF-a: Tumor necrosis factor alpha, IFN- $\mathrm{z}$ : Interferon gamma, CTLs: CD8 ${ }^{+}$cytotoxic lymphocytes, TGF- $\beta$ : Transforming growth factor beta, MDSC: Myeloid-derived suppressor cells 
tumors) contain an abundant level of CTLs with an ability to invade tumor cells which they were derived. Recognition of tumor antigen by specific $\mathrm{T}$ cells is a necessary prerequisite for the induction of effective antitumor immune response [9-11]. Tumor antigen presentation might be mediated by tumor cells in tumor draining lymph nodes (direct presentation) or via crosspresentation by pAPC [12]. Cross priming of naïve $\mathrm{CD}^{+}$ $\mathrm{T}$ cells by pAPC invokes a program leading to tumor specific CTLs which proliferate and traffic to the tumor site where they ultimately attack and destroy tumor cells [13]. CTLs use various mechanisms to kill tumor cells through granzymes, perforin [14-16], and ligands of the tumor necrosis factor (TNF) superfamily such as Fas ligand [17]. The anti-tumor effect is also achieved by secretion of Interferon gamma (IFN- $\gamma$ ) [18] and TNF alpha (TNF- $\alpha$ ) [19] from activated $\mathrm{CD} 8^{+} \mathrm{T}$ cells.

Understanding the importance role of $\mathrm{CD}_{4}^{+} \mathrm{T}$ cells in the antitumor immune response has grown dramatically over the past decade. Upon encountering antigens and adequate co-stimulation signals, naive $\mathrm{CD}^{+} \mathrm{T}$ cells are activated, polarized, and differentiated into distinct subsets including Th1, Th2 [20], Tregs [21], Th17, [22], Th9 [23], Th22 [24] and follicular helper $\mathrm{T}$ cells $\left(\mathrm{T}_{\mathrm{FH}}\right)$ [25]. Among these various $\mathrm{CD}_{4}^{+} \mathrm{T}$ cells subpopulations, Th1 subset plays a clear antitumor role by coordinating cellmediated immunity against cancer cells [26]. First and foremost, Th1 cells, by producing large amounts of IFN- $\gamma$ and chemokines, enhance the expansion, priming and infiltration of $\mathrm{CD}^{+} \mathrm{T}$ cells into the tumor site [27]. Importantly, The IFN- $\gamma$ which secreted by Th1 cells exerts anti-proliferative, pro-apoptotic actions and inhibit angiogenesis in tumor cells in a $\mathrm{CD} 8^{+} \mathrm{T}$ cells-independent manner [28]. Th1 cells also recruit and activate inflammatory cells (macrophages, granulocytes, eosinophils and NK cells) in around the tumor [29]. Indeed, Th1 cells can kill MHC-II ${ }^{+}$tumor cells directly through perforine and granzyme, TNF-related apoptosis inducing ligand (TRAIL) receptor and Fas/Fas ligand pathways [30].

NK cells have been gaining importance in recent years as an efficient approach in cancer immunotherapy. These cells are able to clear tumor cells directly through several mechanisms. NK cells induce the tumor cell apoptosis by 1) secretion of cytoplasmic granules, perforin and granzymes [31], 2) expression of death receptor-mediated apoptosis [32] or 3) secretion of TNF- $\alpha$ [33] and destroying tumor cells through antibody dependent cellular cytotoxicity by expressing CD16 [34]. Furthermore, NK cells have an indirect antitumor activity through producing cytokines, chemokines and growth factors [35]. The IFN- $\gamma$ which produced by NK cells is responsible for induction of $\mathrm{CD}^{+} \mathrm{T}$ cells to become CTLs as well as differentiation of $\mathrm{CD}^{+} \mathrm{T}$ cells toward a Th1 response [36]. NK cells also induce inflammatory responses; modulate monocyte, DC, granulocyte growth and differentiation; and enhance subsequent adaptive immune responses through their released cytokines [37].

Macrophages play a vital role in antitumor innate response by elimination of apoptotic tumor cells in order to obviate autoimmunity. During apoptosis, tumor cells express special molecules at their surface (lipid phosphatidylserine, oxidized PS, oxidized low-density lipoprotein and the multi-functional protein calreticulin) which are recognized by macrophages and lead to tumor cell phagocytosis $[38,39]$. In contrast, it has been documented that tumor-associated macrophages type 2 (M2) are responsible for tumor metastasis [40] and progression [41] by promoting the transfer of tumor cells into the local blood vessels [40] and inhibiting of tumor-specific T cells [41].

Tumor antigens have been classified into two categories, 1) tumor-associated antigens (TAAs) which are expressed by more than one type of tumor cells as well as normal tissues and, 2) tumor specific antigens (TSAs), on the other hand, are products of random somatic point mutations induced by physical or chemical carcinogens and therefore expressed uniquely by individual tumors and not by any normal tissue, representing the only true tumor-specific antigens $[42,43]$.

\section{Immune response evasion by tumor}

The mechanisms that allow cancer to evade the antitumor immune response are mainly divided into two categories, intrinsic and extrinsic. Tumor intrinsic mechanism is achieved by immunosuppressive cytokines, vascular endothelial growth factor (VEGF), indoleamine 2,3dioxygenase (IDO), programmed cell death ligand (PD-L), Fas ligand (Fas-L) and Treg. Tumor extrinsic mechanism is mediated by suppressive cells including alternatively activated M2-like tumour-associated macrophages (TAMs), suppressive $\mathrm{T}$ cells, immature APCs, plasmacytoid dendritic cells ( $\mathrm{pDCs}$ ) and heterogeneous population of myeloid-derived suppressor cells (MDSCs) [44].

Lung cancer evades the immune response through multiple mechanisms. For instance, lung cancer cells go through a slow process of immunoediting, in which precancerous cell slowly undergoes selective adaptation to oppose immune surveillance, a phenomenon called "immune sculpting" [45]. Lung cancer cells also disturb the routine processing of their antigens by pAPC through secretion of various proteins including STAT-3, IDO, TGF- $\beta$, and IL-10 $[46,47]$. Besides, the dense fibrotic stroma around tumor region influences antitumor immunity by limiting access of $\mathrm{T}$ cells to tumor cells [48]. Moreover, lung cancer evade the host immune response by down-regulation of $\mathrm{MHC}$ class I molecule expression, thereby rendering any endogenous or therapeutic antitumor $\mathrm{T}$ cell responses ineffective [49]. Finally, lung 
cancer promotes the increase of immune suppressive cells, specifically Treg [50] and MDSC [51]. These immune suppressive cells accumulate in the tumor microenvironment, promote tumor growth, and downregulate antitumor immune responses [50,51].

Recently it was revealed that the immune checkpoint molecules, specifically cytotoxic T-lymphocyte antigen-4 (CTLA-4) and programmed death-1 (PD-1), play an important role in tumor immune response evasion. CTLA-4 is a protein receptor expressed on the surface of CTL following their full activation. The binding between CTLA-4 and B7-1 (CD80) or B7-2 (CD86) on APCs prevents the overactivity of $\mathrm{T}$ cells under normal conditions. During cancer, $\mathrm{T}$ cells express a high level of CTLA-4, so that, cancer can evade the cytotoxic effect of T cells [52, 53]. PD-1 is a surface receptor expressed on the surface of activated T cells, B cells, NK cells, and host tissues. Binding of PD-1 with its ligand (PD-L1) on the surface of APCs leads to the tolerance of T cells $[54,55]$. It has been documented that numerous epithelial cancers express PD-L1 which leads to T-cell anergy through binding with their PD-1 molecules [56].

\section{Lung cancer vaccines}

Over the last 15 years, numerous efforts have been made to enhance a potent antitumor responses using vaccines to target specific tumor-associated antigens. Although, most studies did not reach their final goals, different subsets analysis showed that, those vaccines could an effective strategy to treat several kinds of tumor including lung cancer. Furthermore, numerous studies indicated that combination of therapeutic vaccines with immune checkpoint inhibitors may play a crucial role in the therapy of lung cancer. Finally, it's important to mention that one of the most important aspect in immunotherapy is designing vaccine that stimulate both a potent immune response and a correlative clinical response. In the following section, we will discuss the efficacy of therapeutic vaccines that have been studied extensively in lung cancer.

\section{Melanoma-associated antigen A3 (MAGE-A3) based vaccine}

Melanoma-associated antigen-A3 (MAGE-A3) is normally presented on testes and placenta. It is also considered as a tumor specific antigen that only expressed on the surface of tumor cells such as melanoma, bladder, non small cell lung carcinoma (NSCLC) and hepatocellular cancer [57]. It has been documented that tumor cells expressing MAGE-A3 antigen are not able to present it to the helper $\left(\mathrm{CD}^{+}\right)$and CTLs. So that, this antigen could be used as immunotherapeutic agent to activate an effector immune response against tumor MAGE-A3 expressing cells [58].

In a double-blind, randomized, placebo-controlled phase II study, 182 patients of stage IB/II NSCLC were enrolled to receive the recombinant MAGE-A3 vaccine $(n=122)$ or placebo $(n=60)$. The results showed that there was no significant difference between vaccinated patients and placebo group regarding to disease-free interval (DFI), disease-free survival (DFS), and overall survival (OS) (Table 1). On the other hand, it was recorded that after 44 months, recurrence was observed in $35 \%$ of patients who received recombinant MAGE-A3 vaccine compared with $43 \%$ of patients in placebo group. Interestingly, IgG antibodies against MAGE-A3 has been detected in all MAGE-A3 vaccinated patients which refers to the ability of this vaccine to induce a specific immune response. These results proved the efficiency of MAGE-A3 vaccine with minimal toxicity. This study referred that MAGE-A3 vaccine could still provide benefit in combination with immune checkpoint inhibitors that reverse a tumor's immunosuppressive effects [59].

Table 1 Clinical trials of therapeutic vaccines in lung cancer

\begin{tabular}{|c|c|c|c|c|}
\hline Vaccine & Phase & Pt No. & Stages & Results \\
\hline MAGE-A3 & $\|$ & 182 & $\mid \mathrm{B} / \mathrm{I}$ & $\begin{array}{l}\text { DFI: (HR: } 0.75,95 \% \mathrm{Cl}, 0.46 \text { to } 1.23 \text {; two-sided } P=.254) \text {; DFS: (HR: } 0.76 ; 95 \% \mathrm{Cl}, 0.48 \\
\text { to } 1.21 ; P=.248) ; \mathrm{OS}:(\mathrm{HR}, 0.81 ; 95 \% \mathrm{Cl}, 0.47 \text { to } 1.40 ; P=.454)[59] .\end{array}$ \\
\hline \multirow[t]{2}{*}{ BLP25 } & $\|$ & 171 & $\| \mathrm{II} / \mathrm{IV}$ & $\begin{array}{l}\text { Median OS: } 17.4 \text { months with L-BLP25/BSC vs } 13.0 \text { months with BSC alone [68]. } \\
\text { Subset analysis ( } n=65 \text { ): } \\
\text { Median OS: } 30.6 \text { months with L-BLP25/BSC vs } 13.3 \text { months with BSC alone [69]. }\end{array}$ \\
\hline & III & 1239 & III & $\begin{array}{l}\text { Median OS: } 25.6 \text { months with L-BLP25 vs } 22.3 \text { months with placebo [70]. } \\
\text { Subset analysis (patients with previous chemoradiotherapy): } \\
\text { Median OS: } 30.8 \text { months with L-BLP25 vs } 20.6 \text { months with placebo [70]. }\end{array}$ \\
\hline \multirow[t]{2}{*}{ Belagenpumatucel-L } & $\|$ & 75 & II/IV & Estimated 2-years survival: $52 \%$ with high doses vs $20 \%$ with low doses [75]. \\
\hline & III & 532 & $\| I / / V$ & $\begin{array}{l}\text { Median OS: } 20.3 \text { months with belagenpumatucel-L vs } 17.8 \text { months with placebo [76]. } \\
\text { Subset analysis (patients with pretreatment radiation): } \\
\text { Median OS: } 40.1 \text { months with belagenpumatucel-L vs } 10.3 \text { months with placebo [76]. }\end{array}$ \\
\hline CIMAvax EGF & $\|$ & 80 & $\| \mathrm{IB} / \mathrm{IV}$ & Median survival: 11.7 months with GAR vs 3.6 months with PAR [81]. \\
\hline TG4010 & $\|$ & 148 & $\| \mathrm{IB} / \mathrm{IV}$ & 6-months PFS: $43.2 \%$ with TG4010/chemotherapy vs $35.1 \%$ with chemotherapy alone [84]. \\
\hline
\end{tabular}

Abbreviations: DFI disease free interval, DFS disease-free survival, OS overall survival, HR hazard ratio, BSC best supportive care, PFS progression free survival, GAR good anti-EGF antibody response, PAR poor antibody response 
To overcome the shortages of previous clinical study (small sample size and lacking of adjuvant therapy), the efficacy of MAGE-A3 vaccine was detected in phase III lung cancer which enrolled 2272 patient with NSCLC. Unfortunately, this study has been stopped in 2014 because adjuvant treatment with the MAGE-A3 immunotherapeutic did not increase disease-free survival compared with placebo in patients with MAGE-A3positive surgically resected NSCLC [60].

\section{MUC1 derived liposomal BLP25 vaccine}

MUC1 is a glycoprotein that expressed normally at the surface of epithelial cells in lung, stomach, intestines, eyes and several other organs and over-expressed in colon, breast, ovarian, lung and pancreatic cancers [61, 62]. It consists of four domains, extracellular subunit (20 amino acid tandem repeat domain), a small extracellular domain subunit, a transmembrane domain and a cytoplasm tail [62]. MUC1 supports tumor growth and metastasis depending on its anti-adhesive features, which prevent cell-cell adhesion [63]. The extracellular immunogenic subunit (25 A.A.) of MUC1 combined with the nonspecific adjuvant monophosphoryl lipid $\mathrm{A}$ and three different lipids was combined together to prepare a therapeutic lung cancer vaccine called liposomal BLP25 (L-BLP25, Stimuvax) [64, 65]. In vitro experiments showed that, stimulation of peripheral blood lymphocytes with Stimuvax resulted in induction of a strong MUC1-specific $\mathrm{CD} 8^{+}$ $\mathrm{T}$ cells response [66].

In phase I; Palmer M, et al. [67], have evaluated the safety and immunogenicity of L-BLP25 vaccine in Patients with stage IIIB or IV NSCLC. They found that this vaccine could be administered with minimal toxicity and can elicit a primarily cellular immune response.

An open-label, randomized phase II trial in patients with stage IIIB or IV NSCLC who had underwent any first-line chemotherapy was undertaken to test the efficacy of L-BLP25. 171 patients from 17 centers in Canada and United Kingdom were recruited in this study. Patients were divided into two groups and received MUC1 liposomal vaccine combined the best supportive care (BSC) or only BSC, respectively. The overall survival showed a trend toward longer survival with L-BLP25 plus the BSC vs. BSC alone (median: 17.4 vs. 13.0 months) [68]. A subset analysis of patients with stage IIIb locoregional NSCLC $(n=65)$ showed a trend for improved survival in those patients treated with LBLP25 compared with BSC alone; median OS was 30.6 versus 13.3 months [69] (Table 1).

In phase III trials; Butts $\mathrm{C}$, et al. [70] started a randomized, double-blind trial called START (Stimulating Targeted Antigenic Response To NSCLC) to detect whether L-BLP25 vaccine could improve the survival in patients with stage III unresectable NSCLC when given as maintenance therapy after chemoradiation. 829 patients were received tecemotide vaccine and 410 patients were designate as placebo on a double-blind basis. The results showed that there was no statistically difference in overall survival between vaccinated patients and placebo (25.6 months vs 22.3 months). Interestingly, subgroup analysis revealed that there was a remarkable improvement in the patients who received previous concurrent chemoradiotherapy. The median overall survival for 538 (65\%) of the 829 patients assigned to tecemotide was 30.8 months compared with 20.6 months for the $268(65 \%)$ of 410 patients assigned to placebo (Table 1).

\section{Transforming growth factor- $ß s$ (TGFßs) based vaccines}

TGFß1, TGFß2, and TGFß3 are three highly homologous isoforms members of TGFß superfamily which also consists of more than 30 members (activins, NODAL, etc.) [71]. TGFß expression plays an opposite roles in cancer formation and development. In the primary stage of tumor, TGFß pathway induces cell cycle arrest and apoptosis [72, 73], whereas, in the late stage it supports tumor progression and metastasis [73, 74].

\section{Belagenpumatucel-L vaccine}

Belagenpumatucel-L (Lucanix) vaccine aims to stimulate immune system of NSCLC patients using genetically modified and irradiated whole tumor cells that consist of a TGFß2 antisense gene [75].

In a randomized, dose-variable, phase II clinical trial; belagenpumatucel-L has been tested in 75 patients with NSCLC (stages II-IV), patients were divided into groups and received one of three doses $\left(1.25,2.5\right.$, or $5.0 \times 10^{7}$ cells per injection on a monthly or every other month schedule for up to 16 injections). In the subgroup of 61 late-stage (IIIB and IV) assessable patients showed a a partial response rate of $15 \%$. Importantly, patients who vaccinated with high doses $\left(\geq 25 \times 10^{6}\right.$ cells per injection) showed a better OS than those who vaccinated with low doses $\left(12.5 \times 10^{6}\right.$ cells per injection) with an estimated 2-years survival of $52 \%$ versus $20 \%$, respectively (Table 1). Moreover, a high production level of IFN- - , IL4, and IL-6 cytokines was detected in vaccinated patients who showed a partial responses (PR) or stable diseases (SD) status. This vaccine also recorded an acceptable safety profile [75].

In phase III clinical trial, 532 patients of stage III/IV NSCLC who did not progress after platinum-based chemotherapy were divided into two groups, 270 patients were received belagenpumatucel-L and $262 \mathrm{pa-}$ tients assigned as placebo group. This trial has not achieved its endpoint to improve the overall survival (20.3 months with belagenpumatucel-L vs 17.8 months with placebo). Besides, There were no differences in PFS between two groups (4.3 months with belagenpumatucel-L 
vs 4.0 months with placebo). Although the overall survival was not improved, the subgroup analysis showed that patients with confirmed pretreatment radiation had a median OS of 40.1 months with belagenpumatucel-L compared with 10.3 months for placebo patients. More importantly, Patients with non-adenocarcinoma who were randomized within 12 weeks of the completion of chemotherapy had a median OS of 19.9 months on belagenpumatucel-L, while those who received placebo had an OS of 12.3 months (Table 1). These data, along with a strong safety profile, support the continued development of belagenpumatucel-L for this indication," the investigators concluded, in spite of the study's failure to meet its endpoint [76].

\section{CIMAvax EGF vaccine}

Epidermal growth factor receptor (EGFR) is a member of receptor tyrosine kinases (RTKs) family which consists of EGFR (ErbB1, HER1), ErbB2 (HER2), ErbB3 (HER3) and ErbB4 (HER4). EGFR tyrosine kinase is activated after binding with EGF and can induce a conformational receptor changing by (homo or heterodimer formation), this process is followed by substrate phosphorylation via activated EGFR and activation of downstream pathways which are responsible for cell survival and proliferation [77]. EGFR gene mutation (overactivation) leads to transformation of normal cells to be a malignant cells. The hallmarks of this transformation are, apoptosis suppression, cell proliferation, angiogenesis, metastasis, tumor-induced proinflammatory and immunosuppressive processes $[78,79]$. It has been documented that overexpression of EGFR is associated with lung cancer [80].

CIMAvax EGF vaccine was developed by Cuban researchers to treat NSCLC adult patients with stage IIIB/ IV after receiving conventional first-line chemotherapy through enhancing the own immune system to produce anti EGF antibodies and decrease the serum EGF. In phase II study; 80 NSCLC patients, after finishing firstline chemotherapy, were randomly assigned to receive BSC or EGF vaccine. $51.3 \%$ of vaccinated patients showed an obvious anti-EGF antibody response (good anti-EGF antibody response -GAR-) and in none of the control group (poor antibody response -PAR-) (Table 1). Furthermore, the concentration of Serum EGF was obviously decreased in $64.3 \%$ of vaccinated patients. Interestingly, the researchers found that there was a strong relationship between survival rate and elevation of antibody response and decreasing of serum EGF. CIMAvax EGF vaccine also recorded a good safety profile [81].

\section{TG4010 vaccine}

TG4010 is a therapeutic lung cancer vaccine targeting MUC1 antigen. It consists of attenuated Ankara virus which modified to express MUC1 and IL-2 [82]. It aims to overcome the inhibition status of T-cell response resulted by cancer-associated MUC1 [83].

In phase II clinical trial; 148 patients with stage IIIB/IV NSCLC were divided into two groups, 74 patients received TG4010 combined with chemotherapy (cisplatin-gemcitabine), other 74 patients were received chemotherapy alone. The results revealed that, 6-month PFS was 43.2 $(32 / 74)$ in the TG4010 plus chemotherapy group, and $35.1 \%(26 / 74)$ in the chemotherapy alone group (Table 1$)$. Interestingly, PFS in patients with a normal level of activated natural killer cells (aNK), was obviously higher than control group (58\% vs $38 \%$ ). Besides, the median OS in patients with normal level of aNK cells was higher than patients with high level (18 months vs 11.3 months). The authors concluded that TG4010 could improve the effect of chemotherapy in advanced NSCLC [84].

\section{Immune checkpoint inhibition}

Several studies indicated that immune checkpoints blockade is a very promising in treating a variety of malignancies including lung cancer. Among these immune checkpoint are CTLA-4, PD-1 and PD-L1. Below is a discussion of recent progress made in immunotherapy for lung cancer using immune checkpoint inhibitors.

\section{Inhibition of cytotoxic T-lymphocyte-associated protein 4 (CTLA-4)}

In order to recognize and eliminate tumor cells, CTLs require two activating signals, the first signal is provided by TAAs presented by class I molecules on pAPCs [85]. The second signal is called "costimulatory signal" which is achieved by binding of costimulatory receptor CD28 on $\mathrm{T}$ cells with two costimulatory molecules, $\mathrm{B} 7-1$ (CD80) and B7-2 (CD86) on APCs (Fig. 3a) [86]. Once a CTL becomes activated it expresses a fundamental immunosuppressive molecule called CTLA- 4 on its surface which then binds with costimulatory molecules on APCs about 20 times more avidly than does CD28 (Fig. 3b). The balance between activation and inactivation signals keeps cytotoxic activity in check, while allowing T-cell function to work in a self-limited manner [87]. It has been documented that one of the most important tumor immune evasion mechanisms is upregulation of CTLA-4 expression on $\mathrm{T}$ cells with the help of TGF- $\beta$ during the early stage of tumorigenesis. In recent years significant progress has been made in developing of specific monoclonal antibodies to inhibit CTLA-4 as a potent strategy in cancer immunotherapy (Fig. 3c) [88, 89].

\section{CTLA-4 inhibition by ipilimumab}

Ipilimumab (MDX-010) is a fully human IgG1 monoclonal antibody targeting CTLA-4-mediated T-cell suppression to enhance a potent immune response against 


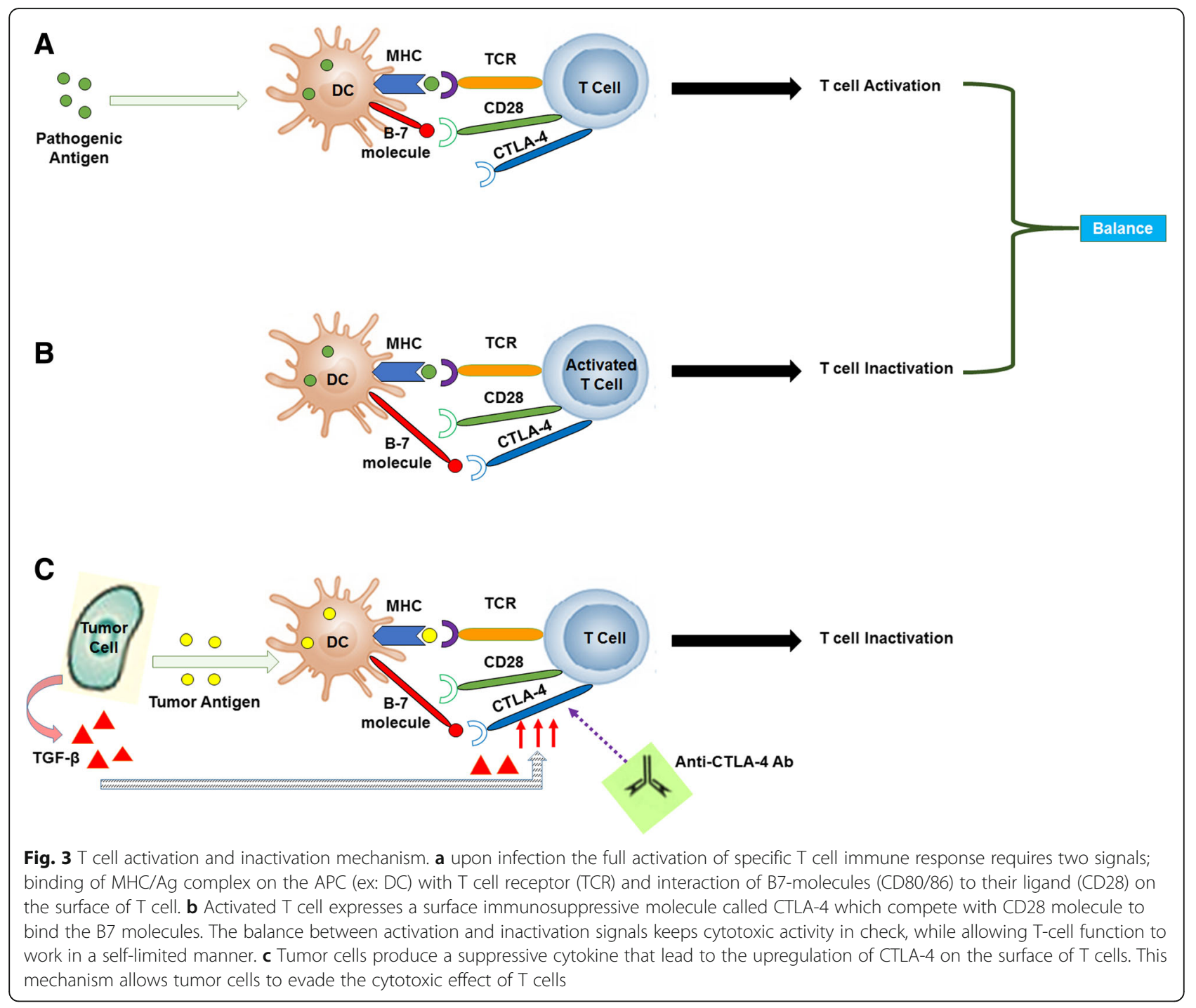

tumors. In double-blind, multicenter phase II clinical trial; depending on the treatment type, NSCLC patients $(N=204)$ were divided into three arms of trial, 1$)$ control (chemotherapy with placebo), 2) concurrent ipilimumab (ipilimumab plus chemotherapy, then, placebo plus chemotherapy) or 3) phased ipilimumab (placebo plus chemotherapy, then, ipilimumab plus chemotherapy). Patients were received treatment intravenously every 3 weeks for 18 weeks. The immune-related progressionfree survival (irPFS) was assessed as the main endpoint besides other endpoints, progression-free survival (PFS), best overall response rate (BORR), immune-related BORR (irBORR), overall survival (OS), and safety [90].

It has been shown that, phased ipilimumab improved irPFS and PFS compared with control group, the median irPFS associated with phased ipilimumab was 5.7 months and the PFS was 5.1 months. Whereas, low irPFS and median PFS were seen in concurrent ipilimumab (irPFS: 5.5 months, PFS: 4.1 months), and control treatments
(irPFS: 4.6 months, PFS: 4.2 months). phased ipilimumab also induced $32 \%$ of irBORR compared with concurrent ipilimumab and control treatments (21 and $18 \%$, respectively). The median OS associated with phased ipilimumab was 12.2 months versus 9.7 and 8.3 months for concurrent ipilimumab and control groups, respectively (Table 2). The following adverse events (AEs) were similar across study arms, fatigue, alopecia, nausea, vomiting, and peripheral sensory neuropathy. Whereas, rash, pruritus, and diarrhea, showed a trend for increased incidence in the ipilimumab-containing arms than in chemotherapy arm [90].

These promising results lead to "A Randomized, Multicenter, Double-Blind, Multinational, phase III trial" (NCT01285609) in NSCLC which started in 2014 to determine whether the combination of ipilimumab and chemotherapy could extend the life of patients with NSCLC compared with chemotherapy alone, as well as, detecting the PFS and OS among enrolled patients. Results are expected to be revealed in late of 2018 . 
Table 2 Results of clinical activity for immune checkpoint inhibitors in lung cancer

\begin{tabular}{|c|c|c|c|c|}
\hline Target & Agent/Ab type & Pt No. & Phase & Results \\
\hline \multirow[t]{3}{*}{$\overline{C T L A-4}$} & $\begin{array}{l}\text { Ipilimumab } \\
\text { lgG1 }\end{array}$ & 204 & $\|$ & $\begin{array}{l}\text { Phased ipilimumab: irPFS: } 5.7 \text { months; PFS: } 5.1 \text { months; Median OS: } 12.2 \text { months. } \\
\text { Concurrent ipilimumab: irPFS: } 5.5 \text { months; PFS: } 4.1 \text { months; Median OS: } 9.7 \text { months. } \\
\text { Control: irPFS: } 4.6 \text { months; PFS: } 4.2 \text { months; Median OS: } 8.3 \text { months [90]. }\end{array}$ \\
\hline & \multirow{2}{*}{$\begin{array}{l}\text { Tremelimumab } \\
\operatorname{lgG} 2\end{array}$} & 87 & $\|$ & ORR: $4.8 \%$; PFS: $20.9 \%$ vs. $14.3 \%$ with supportive care [91]. \\
\hline & & 29 & $\|$ & Disease control: 31 \% of patients, Median PFS: 6.2 months; Median OS: 10.7 months [92]. \\
\hline \multirow[t]{4}{*}{ PD-1 } & \multirow[t]{3}{*}{$\begin{array}{l}\text { Nivolumab } \\
\text { lgG4 }\end{array}$} & 129 & I & $\begin{array}{l}\text { Median OS across doses: } 9.9 \text { months; Median OS: } 14.9 \text { months at } 3 \mathrm{mg} / \mathrm{kg} \text { vs } 9.2 \\
\text { at } 1 \& 10 \mathrm{mg} / \mathrm{kg} ; \text { ORR: } 3 \text { (1 mg/kg), } 24 \text { (3 mg/kg), and } 20 \% \text { (10 mg/kg). 1-year OS } \\
\text { rates at } 3 \mathrm{mg} / \mathrm{kg}: 56 \% \text { [99]. }\end{array}$ \\
\hline & & 117 & $\|$ & $\begin{array}{l}\text { PR: } 14.5 \% \text { of patients; Stable disease: } 26 \% \text { of patients; Median duration: } 6 \text { months; } \\
\text { Median OS: } 8.2 \text { months; } 1 \text {-year OS rates: } 40.8 \% \text { [100]. }\end{array}$ \\
\hline & & 582 & III & $\begin{array}{l}\text { Median OS: } 12.2 \text { months vs } 9.4 \text { months with docetaxel; ORR: } 19.2 \% \text { vs } 12.4 \% \text { with } \\
\text { docetaxel. Median DOR: } 17.1 \text { months vs } 5.6 \text { months docetaxel [101]. }\end{array}$ \\
\hline & $\begin{array}{l}\text { Pembrolizumab } \\
\text { lgG4 }\end{array}$ & 495 & । & ORR: 19.4 \%; Median DOR: 12.5 months; Median PFS: 3.7 Months; Median OS: 12 months [102]. \\
\hline \multirow[t]{5}{*}{ PD-L1 } & \multirow{3}{*}{$\begin{array}{l}\text { Atezolizumab } \\
\text { lgG1 }\end{array}$} & 37 & । & ORR: 24 \%; 24-week PFS: 48 \% [106]. \\
\hline & & 667 & $\|$ & $\begin{array}{l}\text { ORR: } 19 \% \text { when atezolizumab used as a first-line therapy vs } 17 \% \text { when it was a second-line } \\
\text { or subsequent therapy [107]. }\end{array}$ \\
\hline & & 277 & $\|$ & $\begin{array}{l}\text { OS: } 12.6 \text { months with atezolizumab vs } 9.7 \text { with docetaxel; PFS: } 2.7 \text { months with atezolizumab } \\
\text { vs } 3 \text { months with docetaxel; OR: } 14.3 \text { with atezolizumab vs } 7.2 \text { with docetaxel [108]. }\end{array}$ \\
\hline & $\begin{array}{l}\text { BMS-936559 } \\
\operatorname{lgG4}\end{array}$ & 75 & I & ORR: $10 \%$; Stable disease $\geq 24$ weeks: 12 \%; PFS at 24 weeks: $31 \%$ [109]. \\
\hline & $\begin{array}{l}\text { MEDI4736 } \\
\operatorname{lgG1}\end{array}$ & 200 & $|/| \mid$ & ORR: $16 \%$; Disease control rate at 12 weeks: $42 \%$ [110]. \\
\hline
\end{tabular}

Abbreviations: CTLA-4 cytotoxic T-lymphocyte antigen-4, $P D-1$ programmed death 1, $P D$ - $L 1$ programmed death ligand 1, irPFS immune-related progression-free survival, PFS progression-free survival, OS, overall survival, ORR objective response rate, DOR duration of response, OR objective response

\section{CTLA-4 inhibition by tremelimumab}

Tremelimumab (ticilimumab) is a fully human IgG2 monoclonal antibody with high affinity to CTLA-4. In open-label phase II trial; tremelimumab was tested in 87 patients with NSCLC compared with supportive care only following 4 cycles of chemotherapy. PFS in tremelimumab treated patients was $20.9 \%$ compared with $14.3 \%$ in supportive care group (Table 2). The results revealed that $20 \%$ of patients experienced a grade $3 / 4$ AEs, the most common being colitis [91].

In an open-label, single-arm, phase II trial; 29 patients with advanced mesothelioma were received at least one dose of tremelimumab. This trial did not reach its primary endpoint in which only two patients had a durable partial response. On the other hand, a disease control was noted in $31 \%$ of patients with a median PFS of 6.2 months and median OS of 10.7 months (Table 2). 27 patients experienced a grade $1 / 2$ AEs (cutaneous rash, pruritus, colitis, or diarrhea), and 4 patients experienced at least one grade 3/4 AEs (two gastrointestinal, one neurological, two hepatic, and one pancreatic). The authors concluded that tremelimumab could be an effective treatment strategy in previously treated patients with advanced malignant mesothelioma [92].

Currently, tremelimumab is tested in a randomized phase II trial for advanced mesothelioma (NCT01843374) and in combination with other checkpoint inhibitors for treatment of NSCLC (NCT01843374) [93].

\section{PD-1/PDL-1 pathway}

PD-1 (CD279) is a surface receptor on activated T cells, $B$ cells, monocytes, NK cells, and many tumor infiltrating lymphocytes (TILs). Its ligand, PD-L1 (B7-H1; CD274) is expressed on the surface of resting $\mathrm{T}$ cells, $\mathrm{B}$ cells, DCs, macrophages, vascular endothelial cells, and pancreatic islet cells [94]. The binding between PD-1 and PD-L1 leads to transmitting of an inhibitory signal into $\mathrm{T}$ cell which reduces cytokines production and suppresses $\mathrm{T}$ cell proliferation [95]. This pathway plays a crucial role in protecting own body against tissue damage during response to infections [96].

It has been found that PDL-1 is over expressed on tumor cells or on non-transformed cells in the tumor microenvironment [95] in which PD-1/PD-L1 interaction inhibits the proliferation, survival, and effector function of CTL and thus induces apoptosis of TILs (Fig. 4) [97]. Moreover, PD-L1 molecule plays an important role in differentiation of Treg and maintaining their suppressive function. Recently, the development of antiPD agents has taken center stage in cancer immunotherapeutic strategies [98]. 


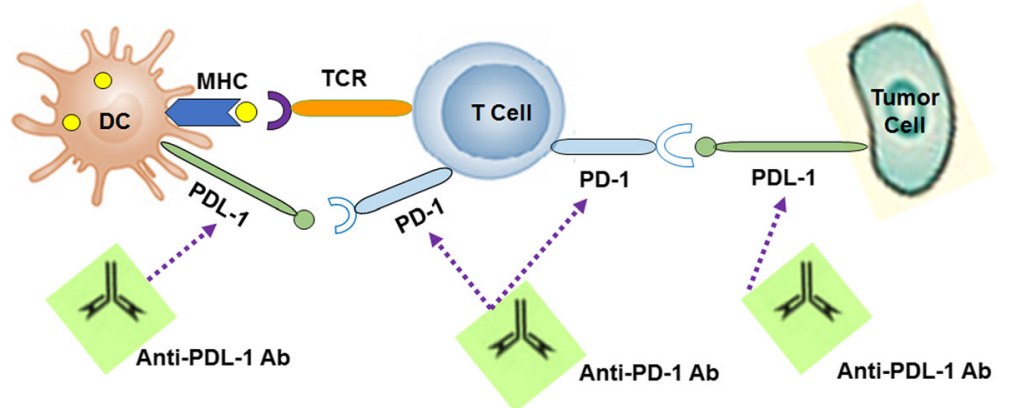

Fig. 4 The mechanism of PD-1/PD-L1 pathway. Programmed cell death-1 (PD-1) receptor is expressed on the surface of activated T cells, B cells, monocytes, NK cells, and many TILs. Its ligand, PD-L1 is expressed on the surface of resting T cells, B cells, dendritic cells, macrophages, vascular endothelial cells, and pancreatic islet cells. The binding between PD-1 and PD-L1 leads to transmitting of an inhibitory signal into the T cell which reduces cytokine production and suppresses T-cell proliferation. PDL-1 is over expressed on tumor cells by which PD-1/PD-L1 interaction inhibits the proliferation, survival, and effector function of CTL and thus induces apoptosis of tumor-infiltrating $T$ cells

\section{Inhibition of PD-1 by nivolumab}

Nivolumab (marketed as Opdivo) is a human monoclonal IgG4 against PD-1. In a phase I study of NSCLC; 129 patients were treated with nivolumab every 2 weeks (doses: 1,3 , or $10 \mathrm{mg} / \mathrm{kg}$ ). The median OS across doses was 9.9 months in all patients. The median OS in patients receiving nivolumab $3 \mathrm{mg} / \mathrm{kg}$ was 14.9 months compared with 9.2 months in both the 1 and $10 \mathrm{mg} / \mathrm{kg}$ cohorts. Across all dose levels, 1-, 2-, and 3-year survival rates were 42,24 , and $18 \%$, respectively. Whereas, At the $3-\mathrm{mg} / \mathrm{kg}$ dose, 1-, 2-, and 3-year OS rates were 56,42 , and $27 \%$, respectively. The objective response rates (ORR) by dose were $3(1 \mathrm{mg} / \mathrm{kg}), 24(3 \mathrm{mg} / \mathrm{kg})$, and $20 \%(10 \mathrm{mg} / \mathrm{kg})$. Among 22 patients (17\%) with objective responses, estimated median response duration was 17 months with 20.6 months of PFS. The most common treatment-related AEs were fatigue, decreased appetite, and diarrhea. Besides, treatment-related select AEs of any grade were observed in $41 \%$ of patients and the most common included skin, GI, and pulmonary events. The authors concluded that nivolumab can induce a durable response and prolong the survival rate in patients with NSCLC [99].

In a phase II, single arm trial, was performed at 27 sites in France, Germany, Italy, and USA. 117 patients with refractory stage IIIB or stage IV squamous NSCLC were administered by intravenous nivolumab $(3 \mathrm{mg} / \mathrm{kg}$ ) every 2 weeks until progression or unacceptable toxic effects. Nivolumab treatment induced a partial response in $14.5 \%$ of patients, including two patients with nontarget baseline central nervous system metastases, with a reduction in tumor burden of at least $50 \%$ for $65 \%$ of these responding patients. Furthermore, nivolumab treatment resulted in stable disease in $30(26 \%)$ patients, with a median duration of 6 months. Median overall survival was 8.2 months and overall survival at 1 year was $40.8 \%$ (Table 2). More importantly, the results indicated that nivolumab had activity in patients with PD-L1-negative and positive tumors. Nivolumab also exhibited a manageable safety profile [100].

In phase III trial; 582 previously treated patients with advanced or metastatic squamous cell NSCLC were divided randomly into two groups, 292 patients were vaccinated subcutaneously with nivolumab every 2 weeks $3 \mathrm{mg} / \mathrm{kg}$, other 290 patients were treated with standard chemotherapy (docetaxel $/ 75 \mathrm{mg} / \mathrm{m}^{2} /$ every 3 weeks). The OS of patients who treated with nivolumab was 12.2 months versus 9.4 months in patients who treated with chemotherapy. Moreover, nivolumab improved the ORR compared with docetaxel $(19.2 \%$ vs $12.4 \%$ ). The median duration of response induced by nivolumab was higher than that in docetaxel treated patients (17.1 months vs 5.6 months) (Table 2). Treatmentrelated AEs were low in severity with nivolumab and were less frequent with nivolumab than with docetaxel. The most frequently reported treatment-related AEs of any grade in the nivolumab group were fatigue, nausea, decreased appetite, and asthenia. Moreover, treatmentrelated serious AEs were less frequent in the nivolumab group than in the docetaxel group. The following treatment-related select AEs of any grade showed a trend for increased incidence in the nivolumab group, were rash, pruritus, erythema, diarrhea, hypothyroidis, increased alanine aminotransferase level, increased aspartate aminotransferase level, and pneumonitis. Based on these significant results, the FDA approved nivolumab $\left(\right.$ Opdivo $\left.^{\circ}\right)$, made by Bristol-Myers Squibb (BMS), for treatment of advanced squamous NSCLC patients who have stopped responding to chemotherapy [101].

\section{Inhibition of PD-1 by pembrolizumab}

Pembrolizumab (also called: MK-3475, Keytruda) is a humanized antibody against PD-1 receptor. In phase I trial, 495 patients with advanced NSCLC were treated 
with pembrolizumab every 2 weeks or every 3 weeks with two different doses, $2 \mathrm{mg} / \mathrm{Kg}$ or $10 \mathrm{mg} / \mathrm{Kg}$. Among patients, 182 were assessed as a training group and 313 as a validation group. Interestingly, antitumor activity were detected in treated patients without a serious side effects, ORR was $19.4 \%$, and the median duration of response was 12.5 months. The median duration of PFS was 3.7 months, and the median duration of OS was 12.0 months (Table 2). Pembrolizumab had an acceptable side-effect profile by which the most common treatment-related AEs were fatigue, pruritus, and decreased appetite. The only treatment-related AEs of an inflammatory or immune-mediated nature that occurred in more than $2 \%$ of patients were infusion-related reactions, hypothyroidism, and pneumonitis [102].

Other primary data showed that combination of nivolumab and pembrolizumab could be an effective strategy to treat NSCLC patients. In September 2015, The FDA granted and approved pembrolizumab to treat patients with advanced, PD-L1-positive NSCLC [103, 104].

\section{Inhibition of PD-L1 by Atezolizumab}

Atezolizumab (also called: MPDL3280A) is a humanized IgG1 antibody that targets PD-L1 [105]. The results of phase I clinical trial in previously treated NSCLC patients showed a 24 of ORR and $48 \%$ of 24 weeks PFS. Biomarker data analysis proved a correlation between PDL1 status and efficacy of atezolizumab [106] (Table 2).

Phase II clinical trials were performed in two different studies, the first single-arm, phase II (BIRCH) study enrolled 667 patients with stage IIIB/IV or recurrent NSCLC to receive a treatment with atezolizumab as the first line of therapy or a subsequent therapy. $19 \%$ of ORR was recorded when atezolizumab used as a firstline therapy compared with $17 \%$ when it was a secondline or subsequent therapy (Table 2). The most commonly reported AEs were fatigue and nausea. Besides, the authors noted that the efficacy of Atezolizumab is associated with the high level of PD-L1 ligand [107].

In the second phase II, multicentre, open-label (POPLAR) trial, two groups of patients with NSCLC were assessed to detect the efficacy of atezolizumab, the first group consisted of 142 patients and received $1200 \mathrm{mg}$ of atezolizumab once every 3 weeks, the second group assessed 135 patients and treated with $75 \mathrm{mg} / \mathrm{m}^{2}$ of docetaxel once every 3 weeks. The OS was 12.6 months in patients who received atezolizumab, compared with 9.7 months in those who received docetaxel. PFS was similar between groups $(2.7$ months with atezolizumab vs 3 months with docetaxel). Importantly, OR with atezolizumab were durable, with a median duration of 14.3 months versus 7.2 months for docetaxel (Table 2). Furthermore, it has been noted that increasing improvement of OS was associated with high expression of PD-
L1. A good safety profile and toleration were recorded in atezolizumab treated patients compared with those who treated with docetaxel. $40 \%$ of patients in the atezolizumab group experienced grade 3-4 adverse events versus $53 \%$ in the docetaxel group. The most common atezolizumab-related grade 3 AEs were pneumonia and increased aspartate aminotransferase. No atezolizumabrelated grade 4 AEs were reported. This study also confirmed the results of BIRCH trial results which showed that atezolizumab has a good efficacy in patients with the highest levels of PD-L1 [108].

In February 2015, the FDA approved atezolizumab to treat PD-L1-positive NSCLC patients who has not showed a response to chemotherapy. The randomized phase III trial for this indication is in-progress (NCT02486718).

\section{Inhibition of PD-L1 by BMS-936559}

BMS-936559 is a human IgG4 monoclonal antibody with high affinity to PDL1. In a multicenter phase I trial; 75 patients with NSCLC were received BMS-936559 every 2 weeks with escalating doses for a maximum of 2 years. The results showed that 10 of treated patients achieved a partial response, and $12 \%$ had stable disease for at least 24 weeks. PFS at 24 weeks was $31 \%$. However, further results from this study are pending. Drugrelated AEs were observed in $39 \%$ of patients and included rash, hypothyroidism, hepatitis, and one case each of sarcoidosis, endophthalmitis, diabetes mellitus, and myasthenia gravis [109].

\section{Inhibition of PD-L1 by MEDI4736}

MEDI4736 (Durvalumab) is an IgG1 antagonist antibody, that blocks PD-L1 binding to PD-1 and CD80, designed with a mutated FC domain to prevent antibodydependent cell mediated cytotoxicity (ADCC). In phase I/II, multicenter, open-label study, 228 patients (126 non-squamous and 102 squamous histology) were enrolled to evaluates the safety and clinical activity of durvalumab. The results showed that, of 200 evaluable treated patients the ORR was $16 \%\left(27 \%\right.$ in PD- $\left.1^{+}\right)$, and disease control rate at 12 weeks was $42 \%$. The ORR in 88 patients with squamous NSCLC was $21 \%$ whereas, in 112 with non-squamous NSCLC, the ORR was $13 \%$ (Table 2). The most frequently Drug-related AEs were fatigue, decreased appetite and nausea [110].

Based on encouraging activity in early trials, durvalumab is currently being evaluated in several phase III trials in NSCLC such as ARCTIC, a global, phase III, randomized, open-label multicenter study (NCT02352948) which aims to asses the 1) safety and clinical activity of durvalumab versus standard of care $(\mathrm{SoC})$ in patients with $\mathrm{PD}-\mathrm{L}^{+}$ tumors; and 2) the combination of durvalumab plus tremelimumab or either agent as monotherapy versus SoC in patients with PD-L1 ${ }^{-}$tumors [111]. 


\section{Conclusions}

In the last few years there has been a growing interest in cancer immunotherapy due to its promising results in achieving significance and durable treatments responses with minimal manageable toxicity. Cancer immunotherapy has many advantages over chemotherapy or radiotherapy. In this regard, immunotherapy is receiving a particular interest due to its favorable benefits, low risk ratio and durable activity. It also showed a significant advantage by controlling tumor growth after patients stop responding to the standard treatments. One of the most important future directions in cancer immunotherapy is identifying predictive markers which can predict the antitumor effect and survival benefit before the implementation of immunotherapies. Combination therapy is another important approach in tumor therapy. Further investigations are needed to evaluate the role of combination the immunotherapeutic agents with one another and with chemotherapy, targeted therapy or other treatment options to treat cancers.

\section{Abbreviations}

AEs: Adverse events; CTLA-4: Cytotoxic T-lymphocyte antigen-4; CTLs: CD8 ${ }^{+}$ cytotoxic lymphocytes; DCs: Dendritic cells; DFI: Disease-free interval; DFS: Diseasefree survival; EGF: Epidermal growth factor; IFN- : Interferon gamma; MAGEA3: Melanoma-associated antigen-A3; MDSCs: Myeloid-derived suppressor cells; NK cells: Natural killer cells; NSCLC: Non small cell lung carcinoma; OS: Overall survival; PAPCs: Professional antigen presenting cells; PD-1: Programmed death-1; PD-L1: Programmed death ligand-1; TAAs: Tumor-associated antigens;

TAM: Tumour-associated macrophages; Treg: Regulatory T cell

\section{Acknowledgments}

We gratefully acknowledge the team of "National Natural Science

Foundation of China" for their support.

\section{Funding}

This work was funded by a grant from the National Natural Science

Foundation of China No. 81271699 (Wang Cailian).

\section{Availability of data and supporting materials}

Not applicable.

\section{Authors' contributions}

Authors have contributed and approved the final manuscript.

\section{Competing interests}

The authors declare that they have no competing interests.

\section{Consent for publication}

Not applicable.

\section{Ethical approval and and consent to participate}

Not applicable.

Received: 14 July 2016 Accepted: 24 September 2016

Published online: 29 September 2016

\section{References}

1. Ferlay J, Soerjomataram I, Dikshit R, Eser S, Mathers C, Rebelo M, et al. Cancer incidence and mortality worldwide: sources, methods and major patterns in GLOBOCAN 2012. Int J Cancer. 2015;136(5):E359-86.

2. Mazzone P, Mekhail T. Current and emerging medical treatments for nonsmall cell lung cancer: a primer for pulmonologists. Respir Med. 2012;106(4): 473-92.
3. Kobayashi S, Boggon TJ, Dayaram T, Janne PA, Kocher O, Meyerson M, et al. EGFR mutation and resistance of non-small-cell lung cancer to gefitinib. $\mathrm{N}$ Engl J Med. 2005;352:786-92.

4. Morgan RA, Dudley ME, Wunderlich JR, Hughes MS, Yang JC, Sherry RM, et al. Cancer regression in patients after transfer of genetically engineered lymphocytes. Science. 2006;314:126-9.

5. Schuster M, Nechansky A, Kircheis R. Cancer immunotherapy. Biogeosciences. 2006;1(2):138-47.

6. Gabrilovich DI, Nagaraj S. Myeloid-derived suppressor cells as regulators of the immune system. Nat Rev Immunol. 2009;9(3):162-74.

7. Zitvogel L, Apetoh L, Ghiringhelli F, André F, Tesniere A, Kroemer G. The anticancer immune response: indispensable for therapeutic success? Clin Invest. 2008;118(6):1991-2001.

8. Liu Y, Zeng G. Cancer and innate immune system interactions: translational potentials for cancer immunotherapy. Immunother. 2012;35(4):299-308.

9. Clark Jr WH, Elder DE, Guerry D, Braitman LE, Trock BJ, Schultz D, et al. Model predicting survival in stage I melanoma based on tumor progression. Natl Cancer Inst. 1989;81(24):1893-904.

10. Gao Q, Qiu SJ, Fan J, Zhou J, Wang XY, Xiao YS, et al. Intratumoral balance of regulatory and cytotoxic T cells is associated with prognosis of hepatocellular carcinoma after resection. Clin Oncol. 2007;25(18):2586-93.

11. Gonzalez-Rodriguez AP, Contesti J, Huergo-Zapico L, Lopez-Soto A, Fernandez-Guizan A, Acebes-Huerta A, et al. Prognostic significance of CD8 and CD4 T cells in chronic lymphocytic leukemia. Leuk Lymphoma. 2010; 51(10):1829-36.

12. Van Mierlo GJ, Boonman ZF, Dumortier HM, den Boer AT, Fransen MF, Nouta J, et al. Activation of dendritic cells that cross-present tumor-derived antigen licenses CD8+ CTL to cause tumor eradication. Immunol. 2004; 173(11):6753-9.

13. Kurts C, Robinson BW, Knolle PA. Cross-priming in health and disease. Nat Rev Immunol. 2010;10(6):403-14.

14. Shresta S, Pham CT, Thomas DA, Graubert TA, Ley TJ. How do cytotoxic lymphocytes kill their targets? Curr Opin Immunol. 1998;10(5):581-7.

15. Cullen SP, Martin SJ. Mechanisms of granule-dependent killing. Cell Death Differ. 2008;15(2):251-62.

16. Cullen SP, Brunet M, Martin SJ. Granzymes in cancer and immunity. Cell Death Differ. 2010;17(4):616-23.

17. Nagata S, Golstein P. The Fas death factor. Science. 1995;267(5203):1449-56

18. Qin Z, Schwartzkopff J, Pradera F, Kammertoens T, Seliger B, Pircher H, Blankenstein T. A critical requirement of interferon gamma-mediated angiostasis for tumor rejection by CD8+ T cells. Cancer Res. 2003;63(14):4095-100.

19. Stoelcker B, Ruhland B, Hehlgans T, Bluethmann H, Luther T, Mannel DN Tumor necrosis factor induces tumor necrosis via tumor necrosis factor receptor type 1-expressing endothelial cells of the tumor vasculature. Am J Pathol. 2000;156(4):1171-6.

20. Mosmann TR, Coffman RL. TH1 and TH2 cells: different patterns of lymphokine secretion lead to different functional properties. Annu Rev Immunol. 1989;7:145-73.

21. Sakaguchi S. Naturally arising Foxp3-expressing CD25 + CD4+ regulatory $T$ cells in immunological tolerance to self and non-self. Nat Immunol. 2005; 6(4):345-52

22. Korn T, Oukka M, Kuchroo V, Bettelli E. Th17 cells: effector T cells with inflammatory properties. Semin Immunol. 2007;19(6):362-71.

23. Végran F, Apetoh $L$, Ghiringhelli F. Th9 cells: a novel CD4 T-cell subset in the immune war against cancer. Cancer Res. 2015;75(3):475-9.

24. Trifari S, Kaplan CD, Tran EH, Crellin NK, Spits H. Identification of a human helper T cell population that has abundant production of interleukin 22 and is distinct from TH-17, TH1 and TH2 cells. Nat Immunol. 2009;10(8):864-71.

25. Crotty S. Follicular helper CD4 T cells (TFH). Annu Rev Immunol. 2011;29: 621-63.

26. Kim HJ, Cantor H. CD4 T-cell subsets and tumor immunity: the helpful and the not-so-helpful. Cancer Immunol Res. 2014;2:91-8.

27. Bos R, Sherman LA. CD4+ T-cell help in the tumor milieu is required for recruitment and cytolytic function of CD8+ T lymphocytes. Cancer Res. 2010;70(21):8368-77.

28. Ikeda H, Old LJ, Schreiber RD. The roles of IFN in protection against tumor development and cancer immunoediting. Cytokine Growth Factor Rev. 2002:13(2):95-109.

29. Galaine J, Borg C, Godet Y, Adotévi O. Interest of Tumor-Specific CD4 T Helper 1 Cells for Therapeutic Anticancer Vaccine. Vaccines. 2015;3(3):490-502. Disis ML (Nora), ed 
30. Haabeth OW, Tveita AA, Fauskanger M, Schjesvold F, Lorvik KB, Hofgaard PO, et al. How Do CD4+ T cells detect and eliminate tumor cells that either Lack or express MHC class II molecules? Front Immunol. 2014;5:174.

31. Trapani JA, Davis J, Sutton VR, Smyth MJ. Proapoptotic functions of cytotoxic lymphocyte granule constituents in vitro and in vivo. Curr Opin Immunol. 2000;12(3):323-9.

32. Cretney E, Takeda K, Yagita H, Glaccum M, Peschon JJ, Smyth MJ. Increased susceptibility to tumor initiation and metastasis in TNFrelated apoptosisinducing ligand-deficient mice. Immunol. 2002;168(3):1356-61.

33. Sutlu T, Alici E. Natural killer cell-based immunotherapy in cancer: current insights and future prospects. Intern Med. 2009;266(2):154-81.

34. Smyth MJ, Hayakawa Y, Takeda K, Yagita H. New aspects of natural killer-cell surveillance and therapy of cancer. Nat Rev Cancer. 2002;2(11):850-61.

35. Vivier E, Tomasello E, Baratin M, Walzer T, Ugolini S. Functions of natural killer cells. Nat Immunol. 2008;9(5):503-10.

36. Martin-Fontecha A, Thomsen LL, Brett S, Gerard C, Lipp M, Lanzavecchia, Sallusto F. Induced recruitment of NK cells to lymph nodes provides IFNgamma for $\mathrm{T}(\mathrm{H}) 1$ priming. Nat Immunol. 2004;5(12):1260-5.

37. Wu J, Lanier LL. Natural killer cells and cancer. Adv Cancer Res. 2003;90:127-56.

38. Gardai SJ, Bratton DL, Ogden CA, Henson PM. Recognition ligands on apoptotic cells: a perspective. Leukoc Biol. 2006;79(5):896-903.

39. Jeannin $P$, Jaillon $S$, Delneste $Y$. Pattern recognition receptors in the immune response against dying cells. Curr Opin Immunol. 2008;20(5):530-7.

40. Wyckoff JB, Wang Y, Lin EY, Li JF, Goswami S, Stanley ER, et al. Direct visualization of macrophage-assisted tumor cell intravasation in mammary tumors. Cancer Res. 2007;67(6):2649-56.

41. Kryczek I, Zou L, Rodriguez P, Zhu G, Wei S, Mottram P, et al. B7-H4 expression identifies a novel suppressive macrophage population in human ovarian carcinoma. Exp Med. 2006;203(4):871-81.

42. Prehn RT. Analysis of antigenic heterogeneity within individual 3methylcholanthrene-induced mouse sarcomas. Natl Cancer Inst. 1970; 45(5):1039-45.

43. Wortzel RDC, Philipps HS. Multiple tumor-specific antigens expressed on a single tumour cell. Nature. 1983;304:165-7.

44. Oleinika K, Nibbs RJ, Graham GJ, Fraser AR. Suppression, subversion and escape: the role of regulatory $T$ cells in cancer progression. Clin Exp Immunol. 2013;171(1):36-45.

45. Matsushita H, Vesely MD, Koboldt DC, Rickert CG, Uppaluri R, Magrini VJ, et al. Cancer exome analysis reveals a T-cell-dependent mechanism of cancer immunoediting. Nature. 2012;482(7385):400-4.

46. Derniame S, Vignaud JM, Faure GC, Bene MC. Alteration of the immunological synapse in lung cancer: a microenvironmental approach. Clin Exp Immunol. 2008;154(1):48-55.

47. Kida H, Ihara S, Kumanogoh A. Involvement of STAT3 in immune evasion during lung tumorigenesis. Oncoimmunology. 2013;2(1):e22653.

48. Salmon H, Donnadieu E. Within tumors, interactions between $T$ cells and tumor cells are impeded by the extracellular matrix. Oncoimmunology. 2012;1(6):992-4

49. Ramnath N, Tan D, Li Q, Hylander BL, Bogner P, Ryes L, Ferrone S. Is downregulation of $\mathrm{MHC}$ class I antigen expression in human non-small cell lung cancer associated with prolonged survival? Cancer Immunol Immunother. 2006;55(8):891-9.

50. Woo EY, Yeh H, Chu CS, Schlienger K, Carroll RG, Riley JL, et al. Cutting edge: regulatory $T$ cells from lung cancer patients directly inhibit autologous T cell proliferation. Immunol. 2002;168(9):4272-6.

51. Lesokhin AM, Hohl TM, Kitano S, Cortez C, Hirschhorn-Cymerman D, Avogadri F, et al. Monocytic CCR2+ myeloid-derived suppressor cells promote immune escape by limiting activated CD8 Tcell infiltration into the tumor microenvironment. Cancer Res. 2012;72(4):876-86.

52. Erfani N, Mehrabadi SM, Ghayumi MA, Haghshenas MR, Mojtahedi Z, Ghaderi A, Amani D. Increase of regulatory T cells in metastatic stage and CTLA-4 over expression in lymphocytes of patients with non-small cell lung cancer (NSCLC). Lung Cancer. 2012;77(2):306-11.

53. Jiang Y, Li Y, Zhu B. T-cell exhaustion in the tumor microenvironment. Cell Death Dis. 2015;6(6):e1792.

54. Sauce D, Almeida JR, Larsen M, Haro L, Autran B, Freeman GJ, Appay V. PD1 expression on human CD8 $T$ cells depends on both state of differentiation and activation status. AIDS. 2007;21(15):2005-13.

55. Liang SC, Latchman YE, Buhlmann JE, Tomczak MF, Horwitz BH, Freeman GJ, Sharpe AH. Regulation of PD-1, PDL1, and PD-L2 expression during normal and autoimmune responses. Eur J Immunol. 2003;33(10):2706-16.
56. Wölfle SJ, Strebovsky J, Bartz H, Sähr A, Arnold C, Kaiser C, et al. PD-L1 expression on tolerogenic APCs is controlled by STAT-3. Eur J Immunol. 2011;41(2):413-24

57. Vander Bruggen P, Traversari C, Chomez P, Lurquin C, De Plaen E, Van den Eynde $B$, et al. A gene encoding an antigen recognized by cytolytic $T$ lymphocytes on a human melanoma. Science. 1991;254(5038):1643-7.

58. Brichard VG, Godechal Q. MAGE-A3-specific anticancer immunotherapy in the clinical practice. Oncoimmunology. 2013;2(10):e25995.

59. Vansteenkiste J, Zielinski M, Linder A, Dahabreh J, Gonzalez EE, Malinowski W, et al. Adjuvant MAGE-A3 immunotherapy in resected non-small-cell lung cancer: phase II randomized study results. Clin Oncol. 2013;31(19):2396-403.

60. Vansteenkiste JF, Cho BC, Vanakesa T, De Pas T, Zielinski M, Kim MS, et al. Efficacy of the MAGE-A3 cancer immunotherapeutic as adjuvant therapy in patients with resected MAGE-A3-positive non-small-cell lung cancer (MAGRIT): a randomised, double-blind, placebo-controlled, phase 3 trial. Lancet Oncol. 2016;17(6):822-35.

61. Hollingsworth MA, Swanson BJ. Mucins in cancer: protection and control of the cell surface. Nat Rev Cancer. 2004;4(1):45-60.

62. Bafna S, Kaur S, Batra SK. Membrane-bound mucins: the mechanistic basis for alterations in the growth and survival of cancer cells. Oncogene. 2010; 29(20):2893-904.

63. Tang CK, Apostolopoulos V. Strategies used for MUC1 immunotherapy: preclinical studies. Expert Rev Vaccines. 2008;7(7):951-62.

64. Decoster L, Wauters I, Vansteenkiste JF. Vaccination therapy for non-smallcell lung cancer: review of agents in phase III development. Ann Oncol. 2012;23(6):1387-93.

65. Sangha R, Butts C. L-BLP25: a peptide vaccine strategy in non small cell lung cancer. Clin Cancer Res. 2007;13:S4652-4654.

66. Xia W, Wang J, Xu Y, Jiang F, Xu L. L-BLP25 as a peptide vaccine therapy in non-small cell lung cancer: a review. Thorac Dis. 2014;6(10):1513-20.

67. Palmer M, Parker J, Modi S, Butts C, Smylie M, Meikle A, et al. Phase I study of the BLP25 (MUC1 peptide) liposomal vaccine for active specific immunotherapy in stage IIIB/IV non-small-cell lung cancer. Clin Lung Cancer. 2001:3:49-57. discussion 58

68. Butts C, Murray N, Maksymiuk A, Goss G, Marshall E, Soulières D, et al. Randomized Phase IIB Trial of BLP25 Liposome Vaccine in Stage IIIB and IV Non-Small-Cell Lung Cancer. Clin Oncol. 2005;23(27):6674-81.

69. Butts C, Maksymiuk A, Goss G, Soulieres D, Marshall E, Cormier Y, et al. A multicentre phase IIB randomized controlled study of BLP25 liposome vaccine ( $L$ BLP25 or Stimuvax) for active specific immunotherapy of non-small cell lung cancer (NSCLC): updated survival analysis. Thorac Oncol. 2007;2(8):s332-3.

70. Butts C, Socinski MA, Mitchell PL, Thatcher N, Havel L, Krzakowski M, et al. Tecemotide (L-BLP25) versus placebo after chemoradiotherapy for stage III non-small-cell lung cancer (START): a randomised, double-blind, phase 3 trial. Lancet Oncol. 2014;15(1):59-68.

71. Wakefield LM, Hill CS. Beyond TGFbeta: roles of other TGFbeta superfamily members in cancer. Nat Rev Cancer. 2013:13:328-41.

72. Tian M, Neil JR, Schiemann WP. Transforming growth factor-beta and the hallmarks of cancer. Cell Signal. 2011;23:951-62.

73. Drabsch Y, ten Dijke P. TGF-beta signalling and its role in cancer progression and metastasis. Cancer Metastasis Rev. 2012;31(3-4):553-68.

74. Jakowlew SB. Transforming growth factor-beta in cancer and metastasis Cancer Metastasis Rev. 2006:25(3):435-57.

75. Nemunaitis J, Dillman RO, Schwarzenberger PO, Senzer N, Cunningham C, Cutler J, et al. Phase II study of belagenpumatucel- $L$, a transforming growth factor beta-2 antisense gene-modified allogeneic tumor cell vaccine in non-small-cell lung cancer. Clin Oncol. 2006;10(24):4721-30.

76. Giaccone G, Bazhenova LA, Nemunaitis J, Tan ME, Ramlau JR, Heuvel MM, et al. A phase III study of belagenpumatucel-L, an allogeneic tumour cell vaccine, as maintenance therapy for non-small cell lung cancer. Eur J Cancer. 2015;51(16):2321-9.

77. Linggi B, Carpenter G. ErbB receptors: New insights on mechanisms and biology. Trends Cell Biol. 2006;16:649-56.

78. Kuykendall A, Chiappori A. Advanced EGFR mutation-positive Non-small-cel lung cancer: case report, literature review, and treatment recommendations. Moffitt Cancer Center. 2014;21(1):67-73.

79. Hirsch FR, Varella-García M, Cappuzzo F. Predictive value of EGFR and HER2 overexpression in advanced non-small-cell lung cancer. Oncogene. 2009;28 Suppl 1:S32-7.

80. Rusch V, Baselga J, Cordon-Cardo C, Orazem J, Zaman M, Hoda S, et al. Differential expression of the epidermal growth factor receptor and its 
ligands in primary non-small cell lung cancers and adjacent benign lung. Cancer Res. 1993;53(10 suppl):2379-85.

81. Neninger Vinageras E, de la Torre A, Osorio Rodriguez M, Catalá Ferrer M, Bravo I, Mendoza del Pino M, et al. Phase II randomized controlled trial of an epidermal growth factor vaccine in advanced non-small-cell lung cancer. Clin Oncol. 2008:26:1452-8.

82. Limacher JM, Quoix E. TG4010 A therapeutic vaccine against MUC1 expressing tumors. Oncolmmunology. 2012;1(5):791-2.

83. Agrawal B, Krantz MJ, Reddish MA, Longenecker BM. Cancer-associated MUC1 mucin inhibits human T-cell proliferation, which is reversible by IL-2. Nat Med. 1998:4:43-9.

84. Quoix E, Ramlau R, Westeel V, Papai Z, Madroszyk A, Riviere A, et al. Therapeutic vaccination with TG4010 and first-line chemotherapy in advanced non-small-cell lung cancer: a controlled phase $2 \mathrm{~B}$ trial. Lancet Oncol. 2011:12:1125-33.

85. Nagorsen D, Scheibenbogen C, Marincola FM, Letsch A, Keilholz U. Natural T cell immunity against cancer. Clin Cancer Res. 2003;9(12):4296-303.

86. Greenwald RJ, Freeman GJ, Sharpe AH. The B7 family revisited. Annu Rev Immunol. 2005;23:515-48.

87. Leach DR, Krummel MF, Allison JP. Enhancement of antitumor immunity by CTLA-4 blockade. Science. 1996;271(5256):1734-6.

88. Funt SA, Page DB, Wolchok JD, Postow MA. CTLA-4 antibodies: new directions, new combinations. Oncology (Williston Park). 2014;28 Suppl 3:6-14.

89. Li L, Chao QG, Ping LZ, Xue C, Xia ZY, Qian D, Shi-ang H. The prevalence of FOXP3+ regulatory T-cells in peripheral blood of patients with NSCLC Cancer Biother Radiopharm. 2009;24(3):357-67.

90. Lynch TJ, Bondarenko I, Luft A, Serwatowski P, Barlesi F, Chacko R, et al. Ipilimumab in combination with paclitaxel and carboplatin as first-line treatment in stage IIIB/IV non-small-cell lung cancer: results from a randomized, double-blind, multicenter phase II study. Clin Oncol. 2012; 30(17):2046-54.

91. Zatloukal P, Heo DS, Park K, Kang J, Butts C, Bradford D, et al. Randomized phase II clinical trial comparing tremelimumab (CP-675,206) with best supportive care (BSC) following first-line platinum-based therapy in patients (pts) with advanced nonsmall cell lung cancer (NSCLC). Clin Oncol. 2009; 27(15S):8071. Abstract.

92. Calabrò L, Morra A, Fonsatti E, Cutaia O, Amato G, Giannarelli D, et al. Tremelimumab for patients with chemotherapy-resistant advanced malignant mesothelioma: an open-label, single-arm, phase 2 trial. Lancet Oncol. 2013;14(11):1104-11.

93. Benjamin C, Creelan MD. Update on immune checkpoint inhibitors in lung cancer. Moffitt Cancer Center. 2014;21:1.

94. Keir ME, Butte MJ, Freeman GJ, Sharpe AH. PD-1 and its ligands in tolerance and immunity. Annu Rev Immunol. 2008;26:677-704.

95. Pardoll DM. The blockade of immune checkpoints in cancer immunotherapy. Nat Rev Cancer. 2012;12(4):252-64.

96. Ramsay AG. Immune checkpoint blockade immunotherapy to activate antitumour T-cell immunity. Br J Haematol. 2013;162(3):313-25.

97. Barber DL, Wherry EJ, Masopust D, Zhu B, Allison JP, Sharpe AH, et al. Restoring function in exhausted CD8 T cells during chronic viral infection. Nature. 2006;439(7077):682-7.

98. Francisco LM, Salinas VH, Brown KE, Vanguri VK, Freeman GJ, Kuchroo VK, et al. PD-L1 regulates the development, maintenance, and function of induced regulatory T cells. Exp Med. 2009;206(13):3015-29.

99. Gettinger SN, Horn L, Gandhi L, Spigel DR, Antonia SJ, Rizvi NA, et al. Overall survival and long-term safety of nivolumab (anti-programmed death 1 antibody, BMS-936558, ONO-4538) in patients with previously treated advanced Non-small-cell lung cancer. Clin Oncol. 2015;33(18):2004-12.

100. Rizvi NA, Mazières J, Planchard D, Stinchcombe TE, Dy GK, Antonia SJ, et al. Activity and safety of nivolumab, an anti-PD-1 immune checkpoint inhibitor, for patients with advanced, refractory squamous non-small-cell lung cancer (CheckMate 063): a phase 2, single-arm trial. Lancet Oncol. 2015;16(3):257-65.

101. Borghaei H, Paz-Ares L, Horn L, Spigel DR, Steins M, Ready NE, et al. Nivolumab versus docetaxel in advanced nonsquamous Non-small-cell lung cancer. N Engl J Med. 2015;373(17):1627-39.

102. Garon EB, Rizvi NA, Hui R, Leighl N, Balmanoukian AS, Eder JP, et al. Pembrolizumab for the treatment of non-small-cell lung cancer. N Engl J Med. 2015;372:2018-28.

103. Rizvi N, Garon E, Patnaik A, Gandhi L, Leighl N, Balmanoukian A, et al. Safety and clinical activity of MK-3475 as initial therapy in patients with advanced non-small cell lung cancer (NSCLC). Clin Oncol. 2014;32:507s. suppl; abstract 800.
104. Gettinger S, Shepherd F, Antonia S, Brahmer J, Chow L, Juergens R, et al. First-line nivolumab (anti-PD-1; BMS-936558, ONO-4538) monotherapy in advanced NSCLC: Safety, efficacy, and correlation of outcomes with PD-L1 status. Clin Oncol. 2014;32:512s. suppl; abstract 8024.

105. Soria JC, Cruz C, Bahleda R, Delord JP, Horn L, Herbst RS, et al. Clinical activity, safety, and biomarkers of a PD-L1 blockade in non-small cell lung cancer (NSCLC): additional analyses from a clinical study of the engineered antibody MPDL3280A (anti-PDL1). Eur J Cancer. 2013;49:abstr 3408.

106. Spigel DR, Gettinger SN, Horn L, Herbst RS, Gandhi L, Gordon MS, et al. Clinical activity, safety, and biomarkers of MPDL3280A, an engineered PD-L1 antibody in patients with locally advanced or metastatic non-small cell lung cancer (NSCLC). Clin Oncol. 2013;31:abstr 8008.

107. Besse $B$, Johnson $M$, Jänne PA. Phase II, single-arm trial (BIRCH) of atezolizumab as first-line or subsequent therapy for locally advanced or metastatic PD-L1selected non-small cell lung cancer (NSCLC). Presented at: 2015 European Cancer Congress; September 25-29; Vienna, Austria. Abstract 16LBA.

108. Fehrenbacher L, Spira A, Ballinger M, Kowanetz M, Vansteenkiste J, Mazieres J, et al. Atezolizumab versus docetaxel for patients with previously treated non-small-cell lung cancer (POPLAR): a multicentre, open-label, phase 2 randomised controlled trial. Lancet. 2016;387(10030):1837-46.

109. Brahmer JR, Tykodi SS, Chow LQ, Hwu WJ, Topalian SL, Hwu P, et al. Safety and activity of anti-PD-L1 antibody in patients with advanced cancer. N Engl J Med. 2012;366(26):2455-65.

110. Antonia S, Rizvi N, Brahmer J, Ou SH, Khleif SN, Hwu WJ, et al. Safety and clinical activity of durvalumab (MEDI4736), an anti-programmed cell death ligand-1 (PD-L1) antibody, in patients with non-small cell lung cancer (NSCLC). Cancer Immunol Res. 2016:4:A047.

111. Planchard D, Yokoi T, McCleod MJ, Fischer JR, Kim YC, Ballas M, et al. A phase III study of durvalumab (MEDI4736) with or without tremelimumab for previously treated patients with advanced NSCLC: rationale and protocol design of the ARCTIC study. Clin Lung Cancer. 2016;17(3):232-6.

\section{Submit your next manuscript to BioMed Central and we will help you at every step:}

- We accept pre-submission inquiries

- Our selector tool helps you to find the most relevant journal

- We provide round the clock customer support

- Convenient online submission

- Thorough peer review

- Inclusion in PubMed and all major indexing services

- Maximum visibility for your research

Submit your manuscript at www.biomedcentral.com/submit
Biomed Central 